\title{
Effects of electrical stimulation and age at slaughter on carcass and meat quality of two Sudanese Baggara beef types
}

\author{
A.D.A. Biraima ${ }^{1,2}$, A.M. Mohammed ${ }^{3}$ \& E.C. Webb ${ }^{1 \#}$ \\ ${ }^{1}$ Department of Animal \& Wildlife Sciences, Faculty of Natural and Agricultural Sciences, University of Pretoria, Private \\ Bag X20, Hatfield, 0028, South Africa \\ ${ }^{2}$ Department of Meat Production, Faculty of Animal Production, University of Khartoum, P.O. Box 32, Khartoum-North, \\ Sudan \\ ${ }^{3}$ Animal Production Research Centre, Hillat Kuku, Animal Resources Research Corporation (ARRC), P.O. Box1355, \\ Khartoum, Sudan
}

(Received 10 March 2019; Accepted 24 August 2019; First published online 18 November 2019)
Copyright resides with the authors in terms of the Creative Commons Attribution 4.0 South African Licence.
See: http://creativecommons.org/licenses/by/4.0/za
Condition of use: The user may copy, distribute, transmit and adapt the work, but must recognise the authors and the South African Journal of Animal Science

\begin{abstract}
This study aimed to evaluate the influences of electrical stimulation (ES), age at slaughter, and breed type on muscle $\mathrm{pH}$, the decline in carcass temperature, and meat quality attributes of Sudanese indigenous Baggara cattle. Eighty Baggara bulls, representative of Nyalawi $(n=40)$ and Mesairi $(n=40)$ breed types, were selected at their typical marketing age of about 4.5 years. Electrical stimulation was applied for 30 seconds at 20 minutes post mortem to 20 randomly selected carcasses from each breed type and compared with 20 carcasses from each type that were not electrically stimulated (NES). Samples of the Longissimus dorsi muscle were collected for meat analyses. Breed type showed no significant influence on meat quality characteristics, while ES and age at slaughter did. Electrical stimulation accelerated the carcass $\mathrm{pH}$ decline significantly up to 24 hours post mortem. Meat from electrically stimulated carcasses and younger animals resulted in higher $L^{*}$ values, lower $a^{*}$ values, higher hue values, and better tenderness. Older Mesairi animals had darker meat than their younger counterparts. Electrical stimulation reduced water-holding capacity (WHC), although it had no influence on cooking loss (CL). Meat from older cattle showed better WHC compared with meat from younger animals. The ES treatment decreased the variations in meat tenderness between the younger and older bulls. It is concluded that the use of ES and younger bulls produced more tender meat with better colour. Therefore, these practices should be adopted in Sudan to ensure better beef quality management.
\end{abstract}

Keywords: Longissimus dorsi muscle, meat characteristics, Mesairi, Nyalawi, Sudan

\#Corresponding author: edward.webb@up.ac.za

\section{Introduction}

Sudanese indigenous Baggara cattle provide a major source for the domestic and export beef markets. They are generally owned by nomadic Baggara tribes, who always migrate in search of feed and water (Alsiddig et al., 2010). Baggara cattle are maintained on natural grassland, which is characterized by seasonal fluctuations in the quantity and quality of feed in addition to stresses from high environmental temperature and movement on hoof (Rahman, 2007). These cattle are often herded for 35 to 75 days to the local livestock markets, and are generally slaughtered at relatively mature ages ( $\geq 4$ years old). All these factors could affect meat quality negatively, especially meat tenderness. In Sudan, castration of cattle is not practised for beef production, but it is used when the bulls are used for draft purposes.

Beef consumers regard tenderness as a very important quality characteristic (Miller et al., 2001; Verbeke et al., 2010), while colour is the main factor that is observed when purchasing the product (Mancini \& Hunt, 2005). The cause of variation in meat quality attributes is complex and depends on factors such as species, breed type, age, bodyweight, gender, nutrition, and pre- and post-slaughter handling (Guerrero, 2013).

Electrical stimulation of carcasses is one of the major practices that is used for improving meat quality (Adeyemi \& Sazili, 2014). Electrical stimulation causes muscles to contract, resulting in a high anaerobic 
glycolytic rate, and hastens $\mathrm{pH}$ decline. This leads to early onset of rigor mortis before the carcass temperature drops to values that cause cold shortening and toughening (Simmons et al., 2008; Devine et al., 2014). Electrical stimulation provides an additional means of increasing tenderness through changes in muscle fibre structures either by physical disruption or by increasing the activity of protease enzymes (Hwang et al., 2003; Kadim et al., 2009). Electrical stimulation of carcasses has been used to improve tenderness and colour in beef (McKenna et al., 2003; Nazli et al., 2010; Mombeni et al., 2013; Agbeniga \& Webb, 2014), lamb (Cetin et al., 2012; Pouliot et al., 2014), goat (Biswas et al., 2007; Cetin et al., 2012; Pophiwa et al., 2016), chicken (Kahraman et al., 2011), and pigs (Channon et al., 2003).

However, ES may have negative impacts on WHC in beef by hastening pH decline (Li et al., 2006; Agbeniga \& Webb, 2018). The current focus of the meat industry is to produce a product of good quality and consistent supply. Currently, in Sudan, ES is not used at beef abattoirs. Nor is any technology employed at abattoirs to improve beef quality. Therefore, there is a need to investigate new techniques that may help to achieve a more desirable beef quality. The purpose of this study was to determine the effects of ES, age at slaughter, and breed type on muscle $\mathrm{pH}$, the decline in carcass temperature, and meat quality attributes of Sudanese indigenous Baggara cattle.

\section{Materials and Methods}

This research project was approved by the Animal Ethical Committee of the University of Pretoria, South Africa (approval number: EC076-17). The study was carried out at the Animal Production Research Centre (KUKU) in Sudan. A total of 80 Baggara cattle were selected according to breed type and age. They were divided into two equal groups that were representative of the typical white Nyalawi breed type $(n=40)$ and typical red Mesairi breed type $(n=40)$. Each breed type was divided into two age groups, namely 20 bulls of about 5-5.5 years old, weighing between 280 and $310 \mathrm{~kg}$, and 20 bulls of about 4-4.5 years old, weighing between 240 and $260 \mathrm{~kg}$. All animals were fed the same diet and slaughtered at the adjacent abattoir of the Animal Production Research Centre. Cattle were fasted and offered only ad libitum water for 12 hours before slaughter. Animals were killed and dressed according to the standard Halal method.

One half of the carcasses in each group were randomly selected and electrically stimulated for 30 seconds at 20 minutes post mortem using an electrical stimulator (110 V) (Jarvis, model ECS-1, South Africa). The ambient temperature of the abattoir was $25-30{ }^{\circ} \mathrm{C}$. Carcasses were moved to a chiller $\left(2-4{ }^{\circ} \mathrm{C}\right)$ at approximately $45 \mathrm{~min}$ post mortem and chilled for 24 hours before removing muscle samples. $\mathrm{Muscle} \mathrm{pH}$ and temperature were recorded with a portable $\mathrm{pH} /$ temperature meter (Hanna Instruments, code- HI99163) that is specially designed for the meat processing industry. The values of muscle $\mathrm{pH}$ and temperature were measured at a point between the 10th and 11th ribs on the Longissimus dorsi muscle. They were measured at 10 min ( 0.17 hours), 3 hours, 6 hours, 9 hours, 12 hours, and 24 hours post mortem.

Longissimus dorsi muscle samples were cut between the 9th and 12th ribs of the left side of each carcass at 24 hours post slaughter for meat quality analysis. Muscle samples were left to bloom at $25{ }^{\circ} \mathrm{C}$ (room temperature) for $20 \mathrm{~min}$. Meat colour was taken with a Hunter Lab ColorFlex EZ (Model 45/0 LAV, Hunter Laboratory Associates, Inc., Reston, Virginia, USA) using illuminant D65 at $10^{\circ}$ standard observer to determine $L^{*}$ (lightness), $a^{*}$ (redness), and $b^{*}$ (yellowness) values. Chroma (intensity of the red colour/saturation index) and hue angle (meat discoloration) were determined using these formulas: chroma =

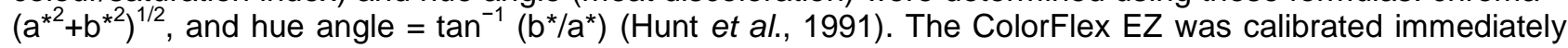
before readings against black and white tiles according to the guidelines of the manufacturer. The mean of three random readings was used for statistical analysis. Each sample was labelled and put in a plastic bag and frozen at $-20^{\circ} \mathrm{C}$ until processing.

The frozen beef samples were thawed at $4{ }^{\circ} \mathrm{C}$ for 36 hours. Water-holding capacity was determined following the procedure of Babiker \& Lawrie (1983), which was based mainly on the evaluation of the amount of water pressed out of the meat under standard conditions. A $0.5 \mathrm{~g}$ minced meat sample was placed on humidified Whatman filter paper (No.4), stored in a desiccator over-saturated potassium chloride solution and pressed between two plexiglass plates at 25 kilograms $(\mathrm{kg})$ weight for 2 minutes. The area of the meat was defined with a ballpoint pen, and the paper was dried. Meat and loose water areas (in $\mathrm{cm}^{2}$ ) were determined with a planimeter to calculate the WHC ratio by the equation "WHC ratio = (loose water area meat film area) /meat film area". A large WHC ratio indicates a high watery condition of the meat or a diminution in the WHC of muscle. For cooking loss $(\mathrm{CL})$, each sample was weighed and put into a plastic bag and cooked in a water bath at $80^{\circ} \mathrm{C}$, while the internal temperature of meat samples reached $70{ }^{\circ} \mathrm{C}$. The cooked samples were chilled overnight at $4{ }^{\circ} \mathrm{C}$. The samples were later blotted dry and weighed. Cooking loss (CL) was calculated as a percentage of the initial weight by the equation "cooking loss $(C L) \%=(($ weight loss after cooking)/ initial sample weight) x 100" (Honikel, 1998).

Beef tenderness was measured by mean of a shear force (SF) test, with a Warner-Bratzler instrument (G-R Elec. Mfg. Co. Manhattan, Kansas 606502). The test was done on the same samples used for cooking 
loss measurements. A preliminary investigation was done to decide the best thickness and enough length of the slice of the meat sample to be clamped and sheared by the instrument. Then, rectangular meat samples (cross-section, $1 \times 1.5 \mathrm{~cm}$ ), $10 \mathrm{~cm}$ long were removed from the cooked muscles. The single peak force value expressed in $\mathrm{kg}$ required to cut the meat samples by shearing perpendicular to the muscle fibres was recorded (Szczesniak, 1963). A mean of 2 single peak force values per sample was recorded for statistical analysis.

Data were analysed as a $2 \times 2 \times 2$ factorial design using SPSS 11.5 for Windows (2003, SPSS version 11.5, SPSS Inc., Chicago, IL, USA). The model used in the analyses of the independent variables $(\mathrm{pH}$, temperature, and meat quality parameters) contained the fixed effects of ES, age at slaughter, and breed type. Appropriate interactions were also estimated, although these were not significant in most cases. Main effect means were thus presented. The results of significant interactions are provided in the text where appropriate. Means of significant interaction were separated by Tukey's test at a 5\% significance level using the Statistix 8.0 for Windows (Analytical Software, Tallahassee, FL, USA). Data were expressed as means \pm standard deviation (SD).

\section{Results and Discussion}

Breed type had no influence on meat quality traits $(P>0.05)$. Generally, the meat quality traits were not affected by the interaction of breed type $\times$ age at slaughter $\times$ ES. Electrical stimulation treatment hastened the carcass $\mathrm{pH}$ decline $(P<0.001)$ up to 24 hours post mortem. The stimulated carcasses had lower $\mathrm{pH}$ values at $1,3,6,9,12$, and 24 hours post mortem compared with the NES carcasses (Figure 1). Mombeni et al. (2013) reported results that were similar to what was observed in the present study in terms of the effect of ES on the decline in beef carcass $\mathrm{pH}$ up to 24 hours post mortem. In other species, Cetin et al. (2012) found that the stimulated carcasses of lamb and goat with different levels of voltage (50, 100, and $250 \mathrm{~V}$ ) resulted in a significant $\mathrm{pH}$ decrease up to 24 hours post mortem compared with non-stimulated ones. However, other studies reported the significant effect of ES on post-mortem pH decline up to 6 hours post mortem (Agbeniga \& Webb, 2014; Polidori et al., 2016; Pophiwa et al., 2016; Agbeniga \& Webb, 2018).

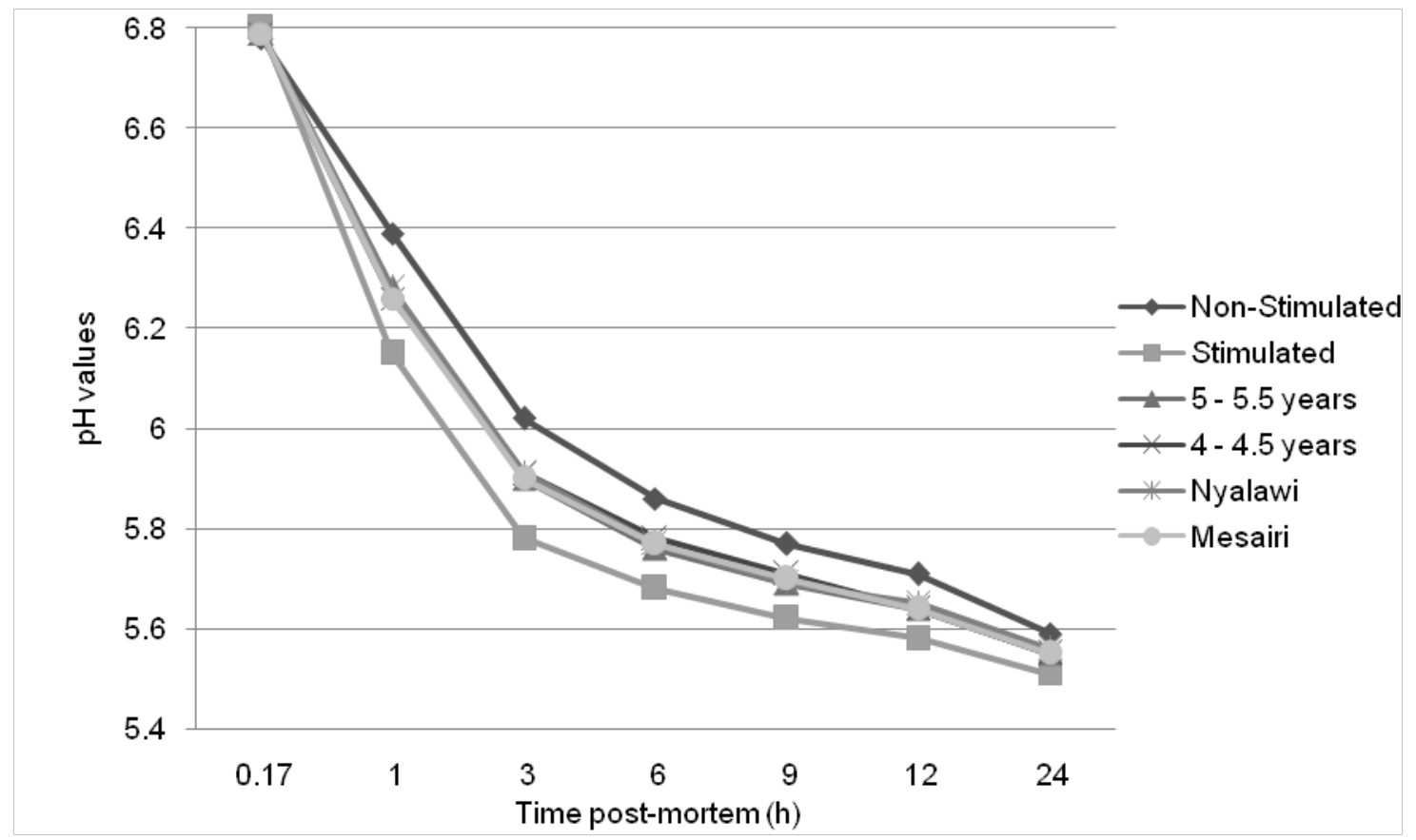

Figure 1 Graphical illustration of the effects of electrical stimulation, age at slaughter, and breed type on $\mathrm{pH}$ decline of Sudanese beef carcasses

The observed effects of ES on the decline in carcass $\mathrm{pH}$ up to 24 hours post mortem may be due to factors that influence the amount of glycogen stored before slaughter. In general, the degree of acidification of post-mortem muscle depends on the muscle glycogen concentrations (Pösö \& Puolanne, 2005). The results of O'Neill et al. (2018) indicate that a short fasting period before slaughter may increase the amount of available muscle glycogen. These authors also found that a short fasting period ante mortem had the 
lowest post-mortem muscle pH values for Brahman cattle at 2, 3, and 9 hours post mortem and Nguni cattle at 6,9 , and 24 hours post mortem. In this study, the feed was withdrawn for 12 hours before slaughter, which could result in high muscle glycogen concentration and explain the prolonging effects of ES on $\mathrm{pH}$ up to 24 hours post mortem.

The other possible reason for the extended effects of ES on muscle $\mathrm{pH}$ could be the lower stress during the ante-mortem period. It is well known that exposure of beef cattle to ante-mortem stress causes low muscle glycogen stores, which eventually results in meat with a high ultimate pH (Njisane \& Muchenje, 2017). Kadim et al. (2010) reported that ES affected the ultimate pH of the non-transported (less stressed) Dofari goat breed. The authors stated that within the non-transported group the stimulated carcasses had lower significant ultimate $\mathrm{pH}(5.61)$ at 24 hours post mortem than the non-stimulated ones (5.75), while the $\mathrm{pH}$ at 24 hours in the transported (more stressed) groups was not affected $(P>0.05)$ by ES. The animals in the present study were not exposed to transportation stress and few other stressors because the feedlot is on the same premises as the abattoir. Neither breed type nor age at slaughter had any influence on muscle $\mathrm{pH}$ decline $(P>0.05)$ (Figure 1). Similar findings were reported by Schutt et al. (2009), Kadim et al. (2009; 2010), and Czyżak-Runowska et al. (2017).

The present study indicates that ES $(110 \mathrm{~V})$ had no significant effect on the carcass temperature decline of Sudanese indigenous Baggara bulls. At 1 hour post mortem, the average temperature value of stimulated carcasses was slightly higher $(32.43 \pm 1.64)$ than NES ones $(31.89 \pm 1.61)$, but not significant $(P$ $>0.05$ ) (Table 1). Similarity, Li et al. (2006) reported that the rate of carcass temperature decline was not affected by low voltage electrical stimulation in Chinese Yellow crossbred bulls. Agbeniga \& Webb (2014) also reported that carcass temperature decline was not influenced by ES. Breed type did not influence the rates of carcass temperature decline $(P>0.05)$, while age at slaughter was significantly affected by the carcass temperature decline (Table 1). Carcasses from animals of 4-4.5 years old that weighed 240-260 kg chilled faster than those from animals of 5-5.5 years old that weighed 280 to $310 \mathrm{~kg}$, and the subsequent carcass temperature values were significantly different at 3 hours, 12 hours, and 24 hours post mortem (Table 1). Obviously, the carcasses with lower weights and from younger bulls contributed to its faster chilling rate.

Table 1 Effects of electrical stimulation, age at slaughter, and breed type on muscle temperature decline in beef carcasses (mean \pm SD)

\begin{tabular}{|c|c|c|c|c|c|c|}
\hline \multirow{2}{*}{ Time } & \multicolumn{2}{|c|}{ Electrical stimulation } & \multicolumn{2}{|c|}{ Age at slaughter (years) } & \multicolumn{2}{|c|}{ Breed type } \\
\hline & NES & ES & $5-5.5$ & $4-4.5$ & Nyalawi & Mesairi \\
\hline $10 \mathrm{~min}$ & $37.83 \pm 0.54$ & $37.86 \pm 0.47$ & $37.92 \pm 0.45$ & $37.77 \pm 0.55$ & $37.80 \pm 0.47$ & $37.90 \pm 0.53$ \\
\hline $1 \mathrm{~h}$ & $31.89 \pm 1.61$ & $32.43 \pm 1.64$ & $32.08 \pm 1.43$ & $32.23 \pm 1.84$ & $32.28 \pm 1.68$ & $32.03 \pm 1.61$ \\
\hline $3 \mathrm{~h}$ & $20.81 \pm 1.91$ & $20.82 \pm 1.63$ & $21.40^{\mathrm{a}} \pm 1.75$ & $20.23^{b} \pm 1.60$ & $20.96 \pm 1.76$ & $20.67 \pm 1.78$ \\
\hline $6 \mathrm{~h}$ & $11.57 \pm 1.14$ & $11.66 \pm 1.21$ & $11.80 \pm 0.97$ & $11.43 \pm 1.33$ & $11.75 \pm 1.35$ & $11.48 \pm 0.96$ \\
\hline $9 \mathrm{~h}$ & $7.60 \pm 1.00$ & $7.65 \pm 1.06$ & $7.70 \pm 0.94$ & $7.55 \pm 1.11$ & $7.65 \pm 1.11$ & $7.59 \pm 0.95$ \\
\hline $12 \mathrm{~h}$ & $5.49 \pm 0.80$ & $5.71 \pm 0.91$ & $5.92^{a} \pm 0.84$ & $5.28^{b} \pm 0.76$ & $5.53 \pm 0.97$ & $5.68 \pm 0.74$ \\
\hline $24 \mathrm{~h}$ & $3.84 \pm 0.39$ & $3.95 \pm 0.39$ & $4.06^{a} \pm 0.29$ & $3.72^{b} \pm 0.41$ & $3.92 \pm 0.44$ & $3.87 \pm 0.34$ \\
\hline
\end{tabular}

In terms of meat colour, the ES group had a higher $(P<0.001)$ mean value in lightness $\left(L^{*}=44.61 \pm\right.$ 1.82) and a lower $(P<0.001)$ mean value in redness $\left(a^{*}=13.74 \pm 1.02\right)$ compared with the NES group $\left(L^{*}=\right.$ $\left.41.61 \pm 1.46 ; a^{*}=14.65 \pm 0.88\right)$. However, no effect $(P<0.05)$ on meat yellowness $\left(b^{*}\right)$ was detected (Figure 2). This shows that electrical stimulation improves meat colour by producing a brighter and better red colour. Similarly, the reports of King et al. (2004) and Nazli et al. (2010) confirmed that ES-treated beef carcasses had a brighter red colour than untreated ones. Carcasses from the ES group had lower $(P<0.05)$ chroma values (chroma $=20.04 \pm 1.01$ ) and higher $(P<0.001)$ hue values (hue $=46.70 \pm 2.39$ ) compared with the NES group (chroma $=20.59 \pm 1.14$; hue $=44.61 \pm 1.72$ ) (Figure 2 ). Low muscle pH values early post mortem combined with high temperature may explain the improvements in meat colour through increased 
protein denaturation and consequently increased light scattering properties of meat (Kim et al., 2014; Hughes et al., 2018).

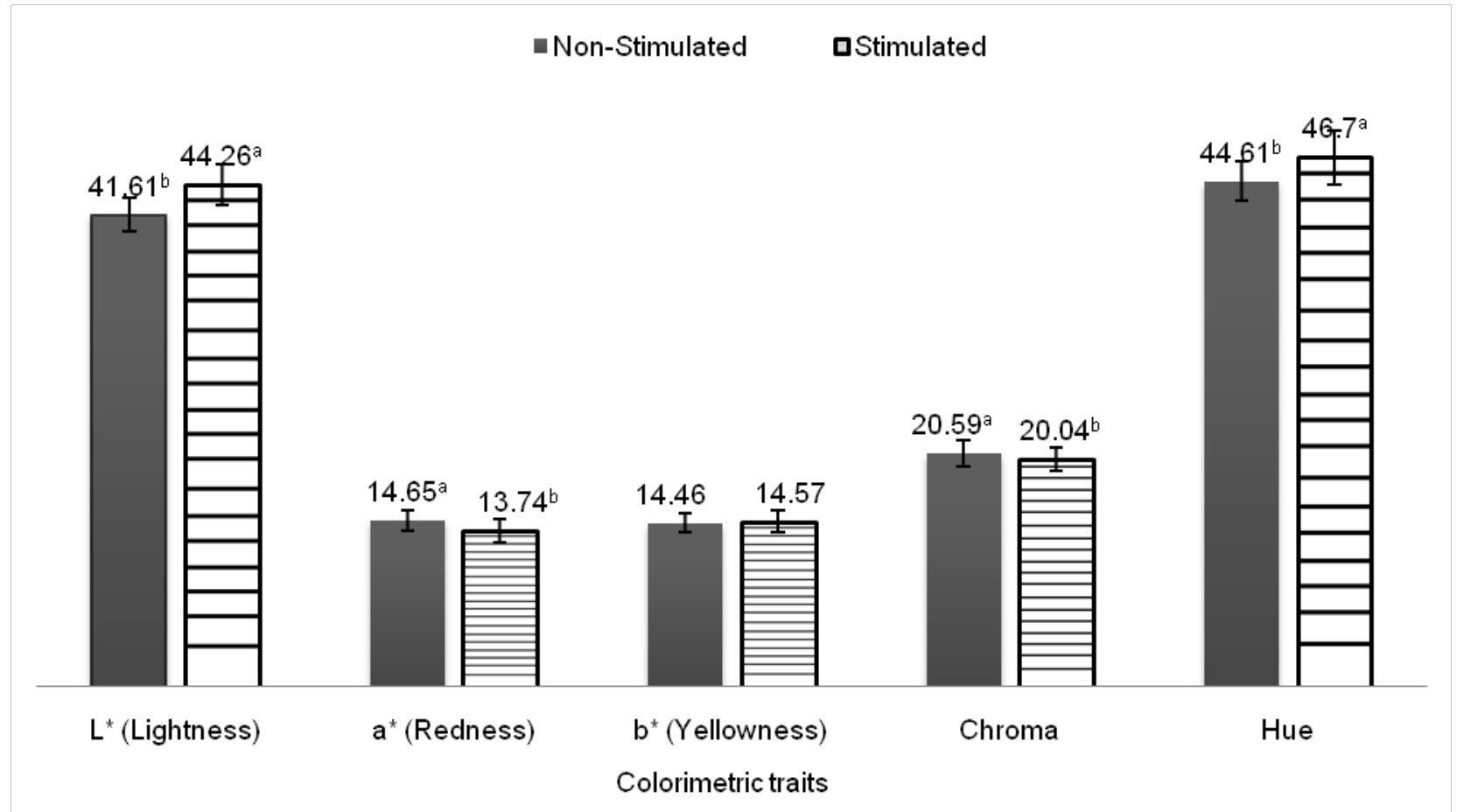

Figure 2 Colorimetric traits of Baggara beef muscle samples between electrical stimulation groups (stimulated versus non-stimulated)

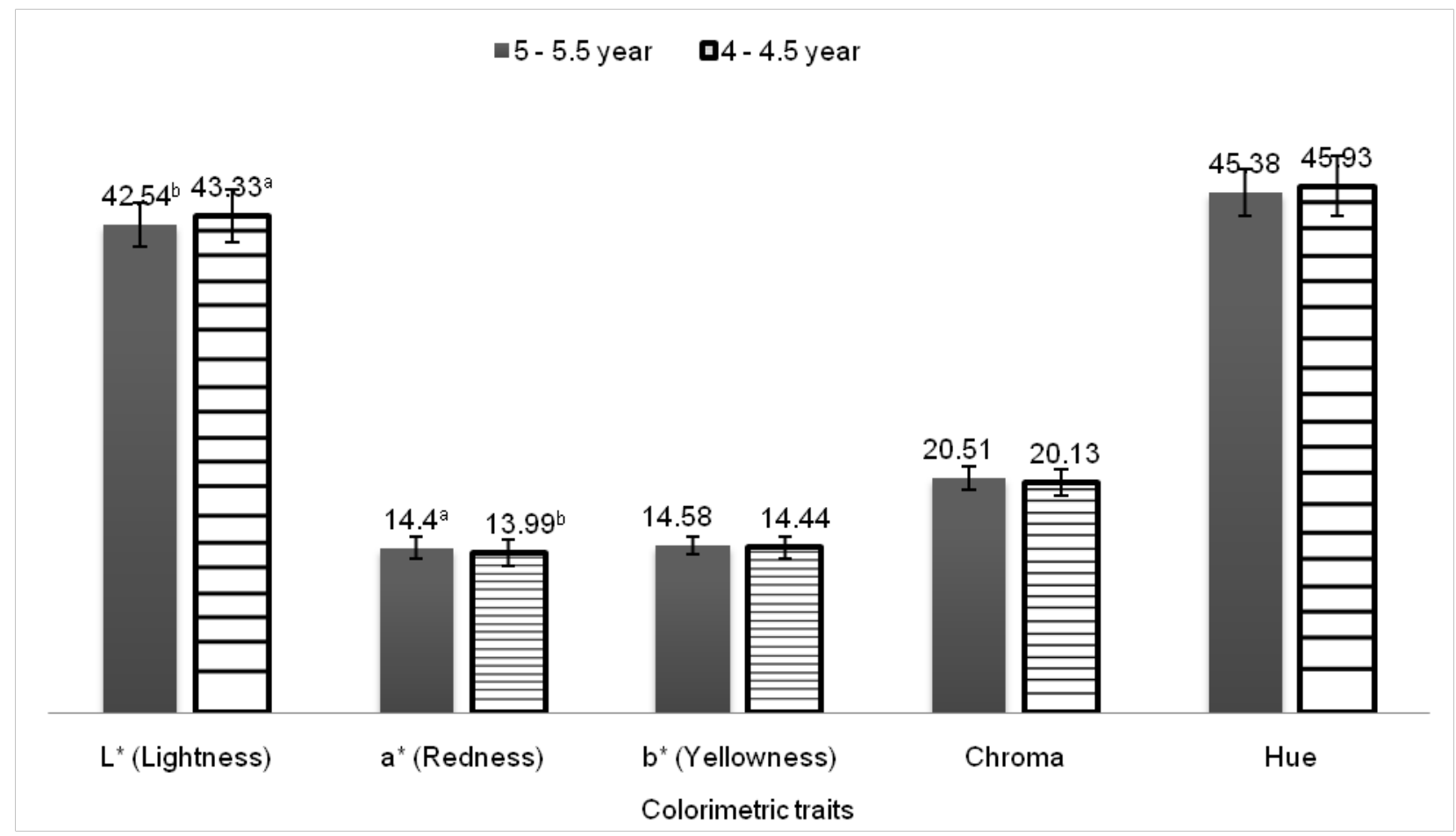

Figure 3 Colorimetric traits of Baggara beef muscle samples between age groups (5-5.5 versus 4-4.5) 
The age group had no influence $(P>0.05)$ on chroma and hue values (Figure 3). Breed type showed no influence on any of the meat colour traits $(P>0.05)$ (Figure 4). However, bulls slaughtered at 4-4.5 years showed the higher $(P<0.05)$ mean value of lightness $\left(L^{*}\right)$ and the lower $(P<0.05)$ mean value of redness $\left(a^{*}\right)$ compared with animals slaughtered at 5-5.5 years (Figure 3 ). The observed variations in the $L^{*}$ could be due to the differences in myoglobin content, since dark meat is associated with increased myoglobin concentration (Lawrie \& Ledward, 2006). In general, the myoglobin concentration increases as the animal ages (Humada et al., 2014). With this increase, the meat from older animals tends to be higher in $a^{*}$ value (redness) and lower in $L^{*}$ value (lightness) (Ponnampalam et al., 2017). Furthermore, younger animals produce meat with lower $a^{\star}$ and chroma values as a result of lower haematin concentration (Vestergaard et al., 2000; Gil et al., 2001; De Palo et al., 2012).

There were only two significant interactions observed for meat colour parameters (Table 2). The first interaction $(P<0.05)$ was between breed type and age at slaughter for the meat lightness $\left(L^{*}\right)$ parameter. Older Mesairi animals had the lowest $L^{*}$ value (darker) compared with their younger counterparts. The second interaction $(P<0.05)$ was found between breed, age at slaughter and electrical stimulation for hue. Mesairi bulls slaughtered at younger ages and subjected to electrical stimulation tended to have higher huge values (47.95 \pm 2.69$)$ than Mesairi bulls slaughtered at older ages and subjected to electrical stimulation $(45.19 \pm 1.53)$.

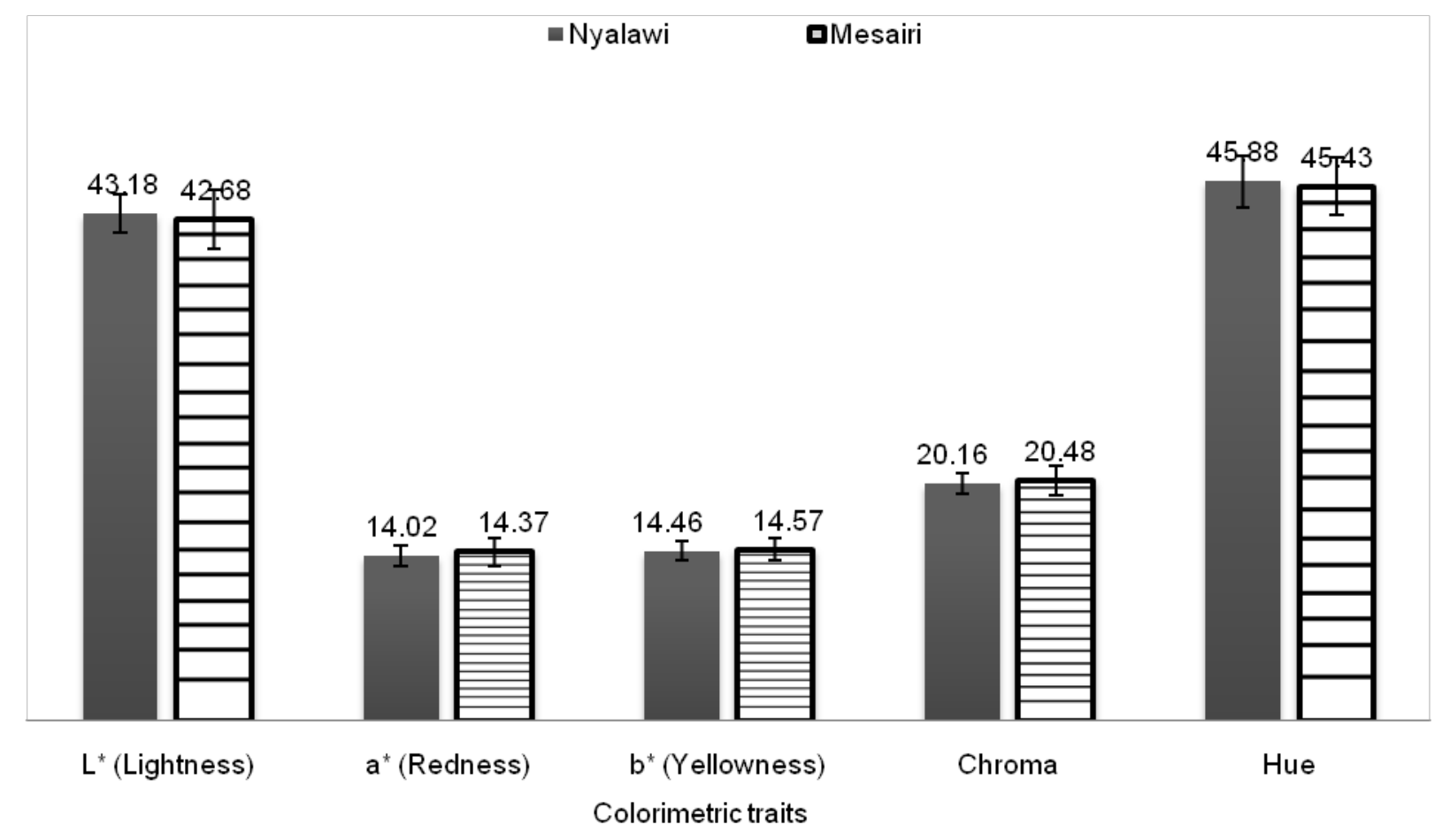

Figure 4 Colorimetric traits of Baggara beef muscle samples between breed type groups (Nyalawi vs. Mesairi breed types)

Water-holding capacity was affected by ES and age at slaughter (Table 3). Electrical stimulation diminished $(P<0.01)$ WHC, but had no effect on cooking losses $(P>0.05)$. A low carcass pH combined with high-temperature causes myosin denaturation, which contributes to lower WHC and higher drip loss (Kim et al., 2014). In this study, ES carcasses reached a low pH value (5.77), whereas the carcass temperature was still high $\left(21.40^{\circ} \mathrm{C}\right)$. This observation agrees with the reports of Li et al. (2006) and Agbeniga \& Webb (2018), who found that ES of beef carcasses resulted in a rapid carcass $\mathrm{pH}$ fall with a reduction in the WHC. The water-holding capacity of the muscles from older animals was better $(P<0.01)$ than the muscles of the younger group. These findings might be due to a diminution in muscle water content with increasing animal age. 
Table 2 Effects of electrical stimulation, age at slaughter, and breed type on colorimetric traits of Sudanese beef muscle samples (mean \pm SD)

\begin{tabular}{|c|c|c|c|c|c|c|c|}
\hline \multicolumn{3}{|l|}{ Treatments } & \multicolumn{5}{|c|}{ Colorimetric traits } \\
\hline Breed type & Age at slaughter & Electrical stimulation & L* (Lightness) & $a^{*}$ (Redness) & $b^{*}$ (Yellowness) & Chroma & Hue \\
\hline \multirow[t]{4}{*}{ Nyalawi } & $5-5.5$ years & NES & $41.95^{d} \pm 1.19$ & $14.68^{\mathrm{ab}} \pm 0.37$ & $14.58 \pm 0.65$ & $20.69 \pm 0.45$ & $44.78^{b c} \pm 1.63$ \\
\hline & & ES & $44.45^{\mathrm{ab}} \pm 0.95$ & $13.80^{\mathrm{ab}} \pm 1.01$ & $14.84 \pm 0.67$ & $20.27 \pm 1.03$ & $47.11^{\mathrm{ab}} \pm 1.78$ \\
\hline & 4-4.5 years & NES & $42.14^{\mathrm{cd}} \pm 1.17$ & $14.18^{\mathrm{ab}} \pm 0.48$ & $14.24 \pm 1.12$ & $20.10 \pm 1.05$ & $45.06^{\mathrm{bc}} \pm 2.05$ \\
\hline & & ES & $44.18^{\mathrm{abc}} \pm 1.41$ & $13.44^{b} \pm 0.91$ & $14.18 \pm 0.72$ & $19.56 \pm 0.67$ & $46.57^{\mathrm{abc}} \pm 2.74$ \\
\hline \multirow[t]{4}{*}{ Mesairi } & $5-5.5$ years & NES & $40.89^{d} \pm 1.66$ & $14.83^{a} \pm 1.07$ & $14.54 \pm 1.06$ & $20.78 \pm 1.31$ & $44.43^{b c} \pm 2.11$ \\
\hline & & ES & $42.85^{\mathrm{bcd}} \pm 1.73$ & $14.29^{\mathrm{ab}} \pm 0.97$ & $14.38 \pm 0.84$ & $20.28 \pm 1.16$ & $45.19^{a b c} \pm 1.53$ \\
\hline & $4-4.5$ years & NES & $41.45^{d} \pm 1.64$ & $14.93^{\mathrm{a}} \pm 1.23$ & $14.48 \pm 1.00$ & $20.80 \pm 1.49$ & $44.15^{c} \pm 1.49$ \\
\hline & & ES & $45.54^{a} \pm 2.07$ & $13.42^{b} \pm 1.09$ & $14.87 \pm 0.93$ & $20.05 \pm 1.08$ & $47.95^{\mathrm{a}} \pm 2.69$ \\
\hline \multicolumn{3}{|l|}{ ANOVA } & & $P$ value & $P$ value & $P$ value & $P$ value \\
\hline \multicolumn{3}{|l|}{ Breed type } & 0.15 & 0.10 & 0.59 & 0.18 & 0.32 \\
\hline \multicolumn{3}{|c|}{ Age at slaughter } & $<0.00$ & $<0.05$ & 0.48 & 0.12 & 0.22 \\
\hline \multicolumn{3}{|c|}{ Electrical stimulation } & $<0.01$ & $<0.01$ & 0.59 & $<0.05$ & $<0.01$ \\
\hline \multicolumn{3}{|c|}{ Breed type $x$ age at slaughter } & $<0.05$ & 0.91 & 0.08 & 0.26 & 0.13 \\
\hline \multicolumn{3}{|c|}{ Breed type $\mathrm{x}$ electrical stimulation } & 0.28 & 0.62 & 0.97 & 0.77 & 0.69 \\
\hline \multicolumn{3}{|c|}{ Age at slaughter $x$ electrical stimulation } & 0.22 & 0.32 & 0.77 & 0.69 & 0.22 \\
\hline \multicolumn{3}{|c|}{ Breed type $x$ age at slaughter $x$ electrical stimulation } & 0.06 & 0.19 & 0.28 & 0.89 & $<0.05$ \\
\hline
\end{tabular}

a,b,c,a Means within the same column with different superscripts differ significantly $(P<0.05)$

ES: electrical stimulation; NES: non-electrical stimulation 
There was an interaction $(P<0.05)$ between age at slaughter and ES. Meat samples from the electrically stimulated carcasses in the older group had a better $(P<0.05)$ WHC $(2.70)$ than meat samples from other groups, followed by ES carcasses in the older group (3.13), NES carcasses in the younger group (3.15) and ES carcasses in the younger group (3.23).

Table 3 Effects of electrical stimulation, age at slaughter and breed type on water-holding capacity, cooking loss, and shear force of Sudanese beef muscle samples (mean \pm SD)

\begin{tabular}{lccc}
\hline \multirow{2}{*}{ Treatments } & \multicolumn{3}{c}{ Parameters } \\
\cline { 2 - 4 } & WHC ratio & $\mathrm{CL} \%$ & $\mathrm{SF}\left(\mathrm{kg} / 1.5 \mathrm{~cm}^{2}\right)$ \\
\hline Electrical stimulation & & & \\
NES & $2.92^{\mathrm{a}} \pm 0.43$ & $21.72 \pm 3.10$ & $7.40^{\mathrm{a}} \pm 0.81$ \\
ES & $3.18^{\mathrm{b}} \pm 0.34$ & $22.26 \pm 2.85$ & $5.83^{\mathrm{b}} \pm 0.66$ \\
Age at slaughter & & & \\
5-5.5 years & $2.91^{\mathrm{a}} \pm 0.40$ & $21.67 \pm 2.93$ & $6.99^{\mathrm{a}} \pm 1.13$ \\
4-4.5 years & $3.19^{\mathrm{b}} \pm 0.37$ & $22.30 \pm 3.09$ & $6.24^{\mathrm{b}} \pm 0.88$ \\
Breed type & & & \\
Nyalawi & $3.01 \pm 0.41$ & $21.42 \pm 2.74$ & $6.51 \pm 0.91$ \\
Mesairi & $3.09 \pm 0.41$ & $22.56 \pm 3.10$ & $6.72 \pm 1.22$
\end{tabular}

\footnotetext{
${ }^{\mathrm{a}, \mathrm{b}}$ Column means with different superscripts within electrical stimulation, age at slaughter, and breed type differ significantly $(P<0.05)$

ES: electrical stimulation; NES: non-electrical stimulation
}

In terms of cooking loss (CL), the main factors (ES, age at slaughter, and breed type) did not influence the percentage of $\mathrm{CL}$ (Table 3). However, meat samples from the ES group lost more water as CL (22.26\%) than the NES group (21.72\%), which may be attributed to the variations in WHC and ultimate $\mathrm{pH}$ between the two ES groups. Previous studies reported significant losses regarding cooking loss between the ES and NES carcasses (Li et al., 2006; Agbeniga \& Webb, 2014). Younger bulls also lost more water as CL (22.30 $\%)$ than the older animals (21.67\%). High moisture content and lower fat content in meat samples from less mature bulls may result in decreasing water binding ability in younger cattle. Likewise, meat samples from the Mesairi-type bulls lost more water as CL (21.42 \%) than those from the Nyalawi type (22.56 \%).

Concerning shear force (SF), as expected, the meat tenderness was affected by ES and age at slaughter (Table 3). The ES carcasses had lower $(P<0.001)$ SF values $\left(5.83 \pm 0.66 \mathrm{~kg} / 1.5 \mathrm{~cm}^{2}\right)$ than those from NES carcasses $\left(7.40 \pm 0.81 \mathrm{~kg} / 1.5 \mathrm{~cm}^{2}\right)$. As reviewed by Bekhit et al. (2014) and Huang et al. (2016), ES accelerates carcass $\mathrm{pH}$ decline, causing early activation of protease enzymes and protein degradation, which increases the meat tenderization process. The observed effect of ES on SF agrees with previous works (Li et al., 2006; McKenna et al., 2003; Nazli et al., 2010; Mombeni et al., 2013; Agbeniga \& Webb, 2014). As anticipated, the SF values were affected significantly by age at slaughter (Table 3). Meat from younger animals showed lower $(P<0.001)$ SF values $\left(6.24 \pm 0.88 \mathrm{~kg} / 1.5 \mathrm{~cm}^{2}\right)$ than those from older animals $\left(6.99 \pm 1.13 \mathrm{~kg} / 1.5 \mathrm{~cm}^{2}\right)$. However, breed type had no influence on SF.

A second-order interaction $(P<0.05)$ was observed between age at slaughter and ES on SF. In the NES carcasses, the younger group had lower $(P<0.05)$ SF values $\left(6.88 \pm 0.67 \mathrm{~kg} / 1.5 \mathrm{~cm}^{2}\right)$ than the older group $\left(7.91 \pm 0.59 \mathrm{~kg} / 1.5 \mathrm{~cm}^{2}\right)$. However, in the ES carcasses, there were no differences $(P>0.05)$ between the younger and older bulls in terms of SF values, but younger bulls still had lower values $(5.60 \pm 0.54 \mathrm{~kg} / 1.5$ $\mathrm{cm}^{2}$ ) compared with older ones $\left(6.06 \pm 0.69 \mathrm{~kg} / 1.5 \mathrm{~cm}^{2}\right)$. Therefore, this study showed that ES reduced the differences in SF values between the younger and older carcasses. There was also a two-way interaction $(P$ $<0.05)$ between breed type and ES for SF values. Regardless of the factors of ES and age at slaughter, the Nyalawi type cattle had a lower $(P<0.05)$ SF value $\left(7.10 \pm 0.67 \mathrm{~kg} / 1.5 \mathrm{~cm}^{2}\right)$, compared with the Mesairi type $\left(7.69 \pm 0.69 \mathrm{~kg} / 1.5 \mathrm{~cm}^{2}\right)$. However, in the ES group, the Mesairi-type cattle recorded a lower SF value (5.75 $\left.\pm 0.60 \mathrm{~kg} / 1.5 \mathrm{~cm}^{2}\right)$ than the Nyalawi-type cattle $\left(5.92 \pm 0.71 \mathrm{~kg} / 1.5 \mathrm{~cm}^{2}\right)$, but the difference was not significant. Therefore, the Mesairi breed type cattle responded better to ES in terms of tenderness compared with the Nyalawi breed type. 


\section{Conclusion}

Breed type did not influence meat quality attributes, but ES and age at slaughter had significant effects. Electrical stimulation accelerated the post mortem pH decline significantly up to 24 hours post mortem. Beef from young animals may help in obtaining high meat quality. This study showed that ES reduced the differences in meat tenderness between younger and older animals. It was also shown that meat from the Mesairi type responded better to ES in terms of tenderness compared with meat from the Nyalawi type. Electrical stimulation of Sudanese Baggara beef carcasses and the use of younger bulls produced more tender meat with better colour. These practices should be adopted in Sudan to improve beef quality.

\section{Acknowledgements}

This research was funded by the University of Pretoria (UP) Postgraduate Research Support Bursary. The authors are grateful to the Animal Production Research Centre (KUKU), Sudan, for providing bulls and abattoir facilities. The support staff at the Animal Production Research centre in Sudan is acknowledged for their technical assistance.

\section{Authors' Contributions}

ECW and ADAB devised the study and performed data analysis. AMM assisted with the experimental animals and abattoir facilities. ADAB performed data collection and wrote the manuscript. ECW provided guidance and reviewed the manuscript.

\section{Conflict of Interest Declaration}

Authors declare that there is no conflict of interest for this work.

\section{References}

Adeyemi, K.D. \& Sazili, A.Q., 2014. Efficacy of carcass electrical stimulation in meat quality enhancement: A review. Asian-Australas. J Anim. Sci. 27, 447-456.

Agbeniga, B. \& Webb, E.C., 2014. Influence of electrical stimulation on carcass and meat quality of Kosher and conventionally slaughtered cattle. S. Afr. J. Anim. Sci. 44, 58-63.

Agbeniga, B. \& Webb, E.C., 2018. Influence of carcass weight on meat quality of commercial feedlot steers with similar feedlot, slaughter and post-mortem management. Food Res. Int. 105, 793-800.

Alsiddig, M.A., Babiker, S.A., Galal, M.Y. \& Mohammed, A.M., 2010. Phenotypic characterization of Sudan Zebu cattle (Baggara type). Res. J. Anim. Vet. Sci. 5, 10-17.

Babiker, S.A. \& Lawrie, R.A. 1983. Post-mortem electrical stimulation and high temperature ageing of hot-deboned beef. Meat Sci. 8, 1-20.

Bekhit, A.E.D.A., Carne, A., Ha, M. \& Franks, P., 2014. Physical interventions to manipulate texture and tenderness of fresh meat: a review. Int. J. Food Prop. 17, 433-453.

Biswas, S., Das, A.K., Banerjee, R. \& Sharma, N., 2007. Effect of electrical stimulation on quality of tenderstretched chevon sides. Meat Sci. 75, 332-336.

Cetin, O., Bingol, E.B., Colak, H. \& Hampikyan, H., 2012. Effects of electrical stimulation on meat quality of lamb and goat meat. The Sci. World J. Article ID 574202, 9 pages.

Channon, H.A., Baud, S.R., Kerr, M.G. \& Walker, P.J., 2003. Effect of low voltage electrical stimulation of pig carcasses and ageing on sensory attributes of fresh pork. Meat Sci. 65, 1315-1324.

Czyżak-Runowska, G., Grześ, B., Pospiech, E., Komisarek, J., Okulicz, M., Stanisławski, D. \& Markiewicz-Kęszycka, M., 2017. Meat quality of Limousin young bulls slaughtered at 6, 9 and 12 months of age. Emirates J. Food Agric. 29, 792-798.

De Palo, P., Maggiolino, A., Centoducati, P. \& Tateo, A., 2012. Colour changes in meat of foals as affected by slaughtering age and post-thawing time. Asian-Australas. J Anim. Sci. 25, 1775-1779.

Devine, C.E., Hopkins, D.L., Hwang, I.H., Ferguson, D.M. \& Richards, I., 2014. Electrical Stimulation. In: Encyclopaedia of Meat Sciences. Eds: Devine, C. \& Dikeman, M., Oxford, UK. pp. 486-496.

Gil, M., Serra, X., Gispert, M., Oliver, M.À., Sañudo, C., ..., García-Cachán, M.D., 2001. The effect of breed-production systems on the myosin heavy chain 1 , the biochemical characteristics and the colour variables of Longissimus thoracis from seven Spanish beef cattle breeds. Meat Sci. 58, 181-188.

Guerrero, A., Velandia Valero, M., Campo, M.M. \& Sañudo, C., 2013. Some factors that affect ruminant meat quality: From the farm to the fork. Review. ActaSci. Anim. Sci. 35, 335-347.

Honikel, K.O., 1998. Reference methods for the assessment of physical characteristics of meat. Meat Sci. 49, 447-457.

Huang, J.C., Yang, J., Huang, F., Huang, M., Chen, K.J., Xu, X.L. \& Zhou, G. H., 2016. Effect of fast pH decline during the early post-mortem period on calpain activity and cytoskeletal protein degradation of broiler M. pectoralis major. Poult. Sci. 95, 2455-2463.

Hughes, J., Clarke, F., Purslow, P. \& Warner, R., 2018. A high rigor temperature, not sarcomere length, determines light scattering properties and muscle colour in beef M. sternomandibularis meat and muscle fibres. Meat Sci. 145, 18.

Humada, M.J., Sañudo, C. \& Serrano, E., 2014. Chemical composition, vitamin E content, lipid oxidation, colour and cooking losses in meat from Tudanca bulls finished on semi-extensive or intensive systems and slaughtered at 12 or 14 months. Meat Sci. 96, 908-915. 
Hunt, M.C., Acton, J.C., Benedict, R.C., Calkins, C.R., Cornforth, D.P., ..., Shivas, S.D., 1991. Guidelines for meat color evaluation. AMSA Committee on Guidelines for Meat Color Evaluation. National Livestock and Meat Board. Chicago, IL, USA.

Hwang, I.H., Devine, C.E. \& Hopkins, D.L., 2003. The biochemical and physical effects of electrical stimulation on beef and sheep meat tenderness. Meat Sci. 65, 677-691.

Kadim, I.T., Mahgoub, O., Al-Marzooqi, O.W. \& Khalaf, S.K., 2009. Effect of low voltage electrical stimulation and splitting the carcass on histochemical and meat quality characteristics of Longissimus thoracis muscle from the one-humped camel (Camelusdromedarius). J. Camelid Sci. 2, 30-40.

Kadim, I.T., Mahgoub, O., Al Marzooqi, W., Khalaf, S., Al Sinawi, S. S. \& Al Amri, I., 2010. Effects of transportation during the hot season, breed and electrical stimulation on histochemical and meat quality characteristics of goat Longissimus muscle. Anim. Sci. J. 81, 352-361.

Kahraman, T., Bayraktaroglu, A.G., Vural, A., Issa, G. \& Ergun, E., 2011. Electron microscopy of contractile bands and quality characteristics in high-voltage electrical stimulation broiler breast meat. Poult. Sci. 90, 486-490.

Kim, Y.H.B., Warner, R.D. \& Rosenvold, K., 2014. Influence of high pre-rigor temperature and fast pH fall on muscle proteins and meat quality: a review. Anim. Prod. Sci. 54, 375-395.

King, D.A., Voges, K.L., Hale, D.S., Waldron, D.F., Taylor, C.A. \& Savell, J.W., 2004. High voltage electrical stimulation enhances muscle tenderness, increases aging response, and improves muscle color from cabrito carcasses. Meat Sci. 68, 529-535.

Lawrie, R.A. \& Ledward, D.A., 2006. The storage and preservation of meat. I. Temperature control. In: Lawrie's Meat Science. 7th ed. CRC, Boca Raton, New York, Washington, DC. pp.192-202.

Li, C.B., Chen, Y.J., Xu, X.L., Huang, M., Hu, T.J. \& Zhou, G.H., 2006. Effects of low-voltage electrical stimulation and rapid chilling on meat quality characteristics of Chinese Yellow crossbred bulls. Meat Sci. 72, 9-17.

Mancini, R.A. \& Hunt, M., 2005. Current research in meat color. Meat Sci. 71, 100-121.

McKenna, D.R., Maddock, D. \& Savell, J.W., 2003. Water holding and color characteristics of beef from electrically stimulated carcasses. J. Muscle Foods 14, 33-49.

Miller, M.F., Carr, M.A., Ramsey, C.B., Crockett, K.L. \& Hoover, L.C, 2001. Consumer thresholds for establishing the value of beef tenderness. J. Anim. Sci. 79, 3062-3068.

Mombeni, E.G., Mombeini, M.G., Figueiredo, L.C., Siqueira, L.S.J., Dias, DT. \& Mombeini, A.G., 2013. Effects of high voltage electrical stimulation on the rate of $\mathrm{pH}$ decline, meat quality and colour stability in chilled beef carcasses. Bangl. Vet. 30, 33-38.

Nazli, B., Cetin, O., Bingol, E.B., Kahraman, T. \& Ergun, O., 2010. Effects of high voltage electrical stimulation on meat quality of beef carcasses. J. Anim. Vet. Adv. 9, 556-560.

Njisane, Y.Z. \& Muchenje, V., 2017. Farm to abattoir conditions, animal factors and their subsequent effects on cattle behavioural responses and beef quality - A review. Asian-Australas. J Anim. Sci. 30, 755-764.

O'Neill, H.A., Webb, E.C., Frylinck, L. \& Strydom, P.E., 2018. Effects of short and extended fasting periods and cattle breed on glycogenolysis, sarcomere shortening and Warner-Bratzler shear force. S. Afr. J. Anim. Sci. 48, 71-80.

Polidori, P., Ariani, A., Micozzi, D. \& Vincenzetti, S., 2016. The effects of low voltage electrical stimulation on donkey meat. Meat Sci. 119, 160-164.

Ponnampalam, E.N., Hopkins, D.L., Bruce, H., Li, D., Baldi, G. \& Bekhit, A.E.D., 2017. Causes and contributing factors to "dark cutting" meat: Current trends and future directions: A review. Compr. Rev. Food Sci. Food Saf. 16, 400-430.

Pophiwa, P., Webb, E.C. \& Frylinck, L., 2016. Meat quality characteristics of two South African goat breeds after applying electrical stimulation or delayed chilling of carcasses. Small Rum. Res.145, 107-114.

Pösö, A.R. \& Puolanne, E., 2005. Carbohydrate metabolism in meat animals. Meat. Sci. 70, 423-434.

Pouliot, E., Gariépy, C., Thériault, M. \& Castonguay, F.W., 2014. Use of electrical stimulation and chilling to enhance meat tenderness of heavy lambs. Can. J. Anim. Sci. 94, 627-637.

Rahman, I.M.K.A., 2007. Sudanese cattle resources and their productivity: A review. Agri. Rev. 28, 305-308.

Schutt, K.M., Burrow, H.M., Thompson, J.M. \& Bindon, B.M., 2009. Brahman and Brahman crossbred cattle grown on pasture and in feedlots in subtropical and temperate Australia. 2. Meat quality and palatability. Anim. Prod. Sci. 49, 439-451.

Simmons, N.J., Daly, C.C., Cummings, T.L., Morgan, S.K., Johnson, N.V. \& Lombard, A., 2008. Reassessing the principles of electrical stimulation. Meat Sci. 80, 110-122.

Szczesniak, A.S., 1963. Classification of textural characteristics. J. Food Sci. 28, 385-389.

Verbeke, W., Van Wezemael, L., de Barcellos, M.D., Kügler, J.O., Hocquette, J.F., Ueland, Ø. \& Grunert, K.G., 2010. European beef consumers' interest in a beef eating-quality guarantee: Insights from a qualitative study in four EU countries. Appetite 54, 289-296.

Vestergaard, M., Oksbjerg, N. \& Henckel, P., 2000. Influence of feeding intensity, grazing and finishing feeding on muscle fibre characteristics and meat colour of semitendinosus, longissimus dorsi and supraspinatus muscles of young bulls. Meat Sci. 54, 177-185. 